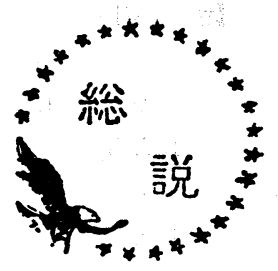

\section{1. 最近の石油需給}

1）需要減退の傾向

石油危機以来, きわめて緊迫していた世界の石油需 給状況は，3月の対米 embargo の解除を契機とした かのように, 急激に緩和しはじめ, 最近では, むし ろ, 原油の供給過剩気味の傾向が強い。アメリカの連 邦エネルギー庁は, 本年 6 月はじめに, ワシントンの 「エネルギー調整グループ」の作業部会に，「1974年 の上半期の世界石油需要は, 一日あたり平均 4,800 万 bbl, 下期には 4, 830 万 bbl と想定されるが, 供給は, 上半期 1 日あたり 4,983 万 bbl， 下期には 4,980 万 bbl で，それぞれ 183 万 bbl および 150 万 bbl の過 剩, 75 年上期には需要 4,830 万 bbl，供給は 5,100 万 bbl で，一日あたり 270 万 bbl の過剩が予想される」 といら報告書を提出している。サイモン財務長官は, 今夏，1974年のこれから年末までは，1日あたり 150 万 bbl ないし 200 万 bbl の過剩があるだろうと言い， サウジ・アラビアのヤマニ石油相ですら，現在の世界 の石油過剩は，4\% ないし $5 \%$ と認めていた。また， 最近のロンドン筋の情報では，「世界の石油生産は， 現在一日あたり 400 万 bbl までの過剩となっており， ……」, 「世界の石油貯蔵施設は, 消費国でも産油国で もいっぱいである……と報じている。簡単に言え ば, 中東の石油生産は, アラブ石油輸出禁止前よりも 多く, 需要は下がっているという事情である。

主要消費国の石油需要は, 本年に入ってから, 石油 危機の影響を大きく反映してか, 各国とも一様に, 減 退傾向を示してきていることは明らかである。工業国 における執拗な景気停滞の上に, 大中な原油価格の引 上げが，直接の大きな原因とされている。オイル・ア ンド・ガスジャーナル誌 7 月29日号は, アメリカの石 油需給状況をつぎのように報じている。本年になって からのアメリカの国内石油需要は, 上半期は一日あた り 1,655 万 bbl で, 前年同期比 $4.2 \%$ 減, 下期は, 若 干の需要増加が予想されるとしても，1974年を通じた 需要は, 前年比 $2.0 \%$ の減となろうと。なかでも, 前 半期ではガソリン需要は前年同期比 $3.3 \%$ 減, 留出燃
料油 $5.5 \%$ 減, 残渣燃料油 $5.8 \%$ 減, ケロシン系ジェ ット燃料油は約 $11 \%$ 源と, 製品別には各油種ともに大 きな減少であった。

石油需要の落込み傾向は, ヨーロッパでも顕著であ った。PIW 誌の報道によれば，本年になって EC 9 力国の石油需要は, 第 1.4 半期には全製品平均対前年 同期比 $9.5 \%$ 減，とくに軽質燃料油の減は $15 \%$ ，ガソ リンも, 重質燃料油も $9 \%$ の減であった。前期を通じ ての需要は, 概して前年比7 8\%減であるが, 1974年 全体では，前年に比して約 5\% 減となろうと予測され ている。

こうした石油需要の減退傾向は, 石油危機以後の世 界的動向であるが，わが国においても例外でないよう であって，その落込みが，最近めだってきている。国 内の燃料油の販売量だけでみると，昨年の10 12月の 石油危機のさ中にあっては, 需要は月平均 2,110 万 $\mathrm{k} l$ の水準であったが，本年になって $1 \sim 3$ 月では平均月 2,095 万 $\mathrm{k} l, 4 \sim 6$ 月平均は 1,750 万 $\mathrm{k} l$ と, 約半 力年前の需要より平均 350 万 $\mathrm{k} l$ 程度の大きな減少と なっている。

さて, 以上のような世界的な需要減退傾向がいつま で続くのか, このような需要動向が, 石油危機以後, 世界的に醸成されつつある新しい動向なのかどうか。 それは，世界景気の行方とも関連し，また OPEC の 今後の政策動向とも結びついた動きで, 容易に判断し かねる点であろら。

2) 産油国の減産傾向

主要消費国における国内需要の減退傾向は, 産油国 の原油生産の動きに微妙に投影しつつある。アラブ産 油国の原油生産削減戦略が, 正式にいつ解除されたの かは定かではないが，中東の産油国のなかでは，とく にサウジ・アラビアは，3 月以来増産に転じたものも あったが，なかには，クエートのように，石油危機に よる削減水準が定着したかのような国もあって, 生産 政策についての, 中東・アラブ産油国の足並みは, か ならずしも揃っていなかった。それどころか,むしろ 原油公示価格の再引上論をめぐって，6月15日のキト 


\begin{tabular}{|c|c|c|c|}
\hline & & $1 \quad ラ$ & サ \\
\hline \multirow[t]{3}{*}{ 73年 } & 4月 & $580.5(19.5)$ & $735.4(22.7)$ \\
\hline & 5 月 & $588.2(17.4)$ & $832.9(47.8)$ \\
\hline & 6 月 & $583.5(17.5)$ & $751.3(35.3)$ \\
\hline \multicolumn{2}{|c|}{$1 \sim 6$ 月 } & $585.2(20.5)$ & $745.6(31.2)$ \\
\hline \multicolumn{2}{|r|}{ 7月 } & $590.7(19.3)$ & $866.4(60.0)$ \\
\hline \multicolumn{2}{|r|}{ 8月 } & $573.1(14.6)$ & $204.7(34.5)$ \\
\hline \multicolumn{2}{|r|}{ 9月 } & $582.8(15.2)$ & $855.0(33.7)$ \\
\hline \multicolumn{2}{|r|}{ 10月 } & $602.0(16.6)$ & $781.4(18.8)$ \\
\hline \multicolumn{2}{|r|}{ 11月 } & $604.6(8.1)$ & $626.8(-6.3)$ \\
\hline \multicolumn{2}{|r|}{12 月 } & $610.7(7.6)$ & $661.4(-1.6)$ \\
\hline \multicolumn{2}{|c|}{ 73年 平 均 } & $589.7(16.8)$ & $759.5(26.3)$ \\
\hline \multirow[t]{7}{*}{ 74年 } & 1月 & $613.7(4.8)$ & $752.0 C$ \\
\hline & 2 月 & $616.7(5.1)$ & 779.9( \\
\hline & 3 月 & $616.5(5.1)$ & 813.4( \\
\hline & 4月 & $619.4(6.7)$ & $864.7(17.6)$ \\
\hline & 5 月 & $622.3(5.8)$ & 901.7( \\
\hline & 6 月 & $610.3(4.6)$ & $888.8(18.3)$ \\
\hline & 7月 & 610.0 & 878.5 \\
\hline
\end{tabular}

一総会の舞台裏では, 原油価格引下げの強硬論者少 ジ・アラビアを除いて，他の OPEC 諸国は，9月ま では増産を見あわせようとする「紳士協定」を結んだ ほどで，一般には原油増産への動きは，例外であった とみてよい。

そうした経過のなかで, 原油の需給は世界的に過剩 傾向に動くばかりか, 原油市場は, 一時の狂乱的な值 動きの反動で, 逆に沈滞しはじめ, イラン, クェート などの政府取得分原油の入札失敗などもからんで, 後 述のように, スポット価格は下向気味の動きが強くな りつつあり，こうした低迷した原油市場を反映して， 生産の動きも, ようやく減産への傾向があきらかにな ってきている。

クェートは, 政府取得分の 原油 1 日あたり 125 万 bbl の大量の入札に失敗してから, ただちにバイ・バ ック分を除く余剩量を減産することになり， 7 月の生 産を一日あたり55万 bbl 減産した。同国のアチキ石油 相は, 8 月の生産を 1 日あたり 200 万 bbl かそれ以下 を考慮中と現地新聞は伝えているのをはじめ, イラン は，1976年秋までに，1 日あたり 740 万 bbl への増産 目標を，650 680万 bbl まで引下げることにしたと伝 え, また, ナイジェリアは, 直販原油の引取りが思う にまかせないので, $10 \%$ の生産削減の可能性が伝え
表 1 O P E C 諸 国 の

\begin{tabular}{|c|c|c|}
\hline \multirow{2}{*}{$\begin{array}{l}\text { クウ } ェ ー ト ~ \\
267.0(-30.7)\end{array}$} & 1 & アブ ダ \\
\hline & $209.8(43.7)$ & $137.4 C$ \\
\hline $281.3(-1.4)$ & $206.4(53.0)$ & 138.5( \\
\hline $283.0(9.3)$ & $200.0(163.5)$ & 132.8( \\
\hline $303.3(-6.5)$ & 188. $3(27.2)$ & 133.2( \\
\hline $330.1(17.7)$ & $203.1(117.2)$ & $133.7 C$ \\
\hline $296.7(-18.5)$ & $203.9(56.2)$ & 138.2( \\
\hline $350.6(-0.6)$ & $211.2(42.0)$ & 139.8( \\
\hline $311.3(-11.6)$ & 180.2( & 136.2( \\
\hline $247.0(-22.0)$ & $214.8(48.5)$ & 116.8( \\
\hline $254.9(-17.0)$ & $215.9(24.0)$ & 103.1( \\
\hline $301.4(-8.3)$ & $196.6(35.2)$ & 130.8 \\
\hline $283.6(-24.8)$ & $182.1(22.2)$ & 122.3( \\
\hline $284.6(-15.1)$ & $182.8(11.1)$ & 128.4( \\
\hline 284.3( & $183.7(-7.8)$ & 149.9( \\
\hline 263.1( & $200.6(-1.5)$ & $162.6 C$ \\
\hline 284.5( & $161.7(-21.7)$ & 164. 2( \\
\hline 288.5( & $175.2(-12.2)$ & 159. 1( \\
\hline & 180.8 & 165. \\
\hline
\end{tabular}

販られ，サウジ・アラビアでは， 7 月に予定された直 原油の入札が無期延期になるばかりでなく, 石油危機 以来の増産テンポが， 5 月をピークに 6 月から減産し はじめ, 7 月には中東最大の産油会社アラムコの生産 量は 1 日あたり $118,000 \mathrm{bbl}$ 減少するなど, 中東産油 国の生産の動きには，一般的な減産傾向が，ようやく 濃厚になってきた。

表 1 は, 最近 1 力年間の OPEC 諸国の原油生産の 推移を示したものである。サウジ・アラビアを除く, 他の OPEC 諸国の生産の足取り, とくに石油危機以 後の動きは, ほぼ横這いか下降の傾向が強い。中東の 生産, OPEC 全体の今後の供給量増加は, サウジ・ アラビア一国だけの増産テンポにかかっているようで ある。この動きは, ヤマニ石油相の原油公示価格引下 論に歩調をあわせてきたものかどらかは別にしても， 今日のサウジ・アラビアの役割は, OPEC 全体の原 油供給量の調整的な立場に立ちつつあるとも考えられ よう。最近まで, サウジ・アラビアは, 単独でも増産 を進め, 価格引下論を実現しようとしていると考えら れてきた。もし，そのような事態になれば, OPEC は分裂して, むしろ, 主要産油国のサウジ・アラビア は他の産油国よりも, 失うものが多いので, 大規模な 増産は起りそうもないという推測もあった。7 月以降 


\begin{tabular}{|c|c|c|c|c|c|c|c|c|}
\hline 原 & & 産 & 移 & & & \multicolumn{3}{|c|}{ (単位：万 bbl/日) } \\
\hline 力夕 & $-ル$ & 中 & 計 & ビ & ナイジェリア & \multicolumn{2}{|c|}{ ベネズェラ } & アルジェリア \\
\hline 59.1( & $41.7)$ & $2,047.8($ & 12.9) & $233.1 C$ & 105.0( & \multirow{4}{*}{\multicolumn{2}{|c|}{$332.2(\quad 7.0)$}} & 110.0 \\
\hline 58.6( & $42.6)$ & $2,165.7($ & $29.4)$ & 226.4( & $195.4(9.7)$ & & & 110.0 \\
\hline 56.0( & $28.8)$ & $2,063.1($ & $33.0)$ & $228.9(10.2)$ & $199.9(11.7)$ & & & 111.0 \\
\hline 58.9( & $35.3)$ & $2,072.0($ & $20.7)$ & $207.3(-0.3)$ & $195.5(11.1)$ & & & 110.0 \\
\hline 60.6( & $26.7)$ & $2,245.8($ & $39.8)$ & 218.9( & $199.1(10.5)$ & \multirow{2}{*}{\multicolumn{2}{|c|}{$335.1(\quad 5.8)$}} & 110.0 \\
\hline 56.8( & $8.5)$ & $2,179.4($ & 18. 6$)$ & $210.8(0.07)$ & $210.2(11.7)$ & & & 110.0 \\
\hline 60.9( & 27.9) & $2,264.5($ & $21.7)$ & 228.6( & $313.8(14.6)$ & \multirow{3}{*}{\multicolumn{2}{|c|}{338.7}} & 110.0 \\
\hline 59.7( & $9.9)$ & $2,129.7 C$ & 11. 1) & $238.4(11.7)$ & $219.0(15.9)$ & & & 102.0 \\
\hline \multirow{2}{*}{\multicolumn{2}{|c|}{$\begin{array}{l}47.4(-18.8) \\
45.6(-20.7)\end{array}$}} & \multicolumn{2}{|c|}{$1,908.5(-9.8)$} & $116.6(-18.9)$ & $223.8(17.5)$ & & & 88.0 \\
\hline & & $1,942.6($ & $-0.4)$ & $176.9(20.2)$ & $225.6(18.3)$ & \multirow[t]{3}{*}{33.49(} & \multirow[t]{2}{*}{$4.5)$} & 86.0 \\
\hline 57.0( & 18.2) & $2,093.2($ & $17.3)$ & $218.5(-1.3)$ & $205.5(13.1)$ & & & 105.0 \\
\hline \multicolumn{2}{|c|}{$51.8(-10.8)$} & $2,060.3($ & 1.3) & $203.2(-11.9)$ & $218.5(13.6)$ & & & $110.0(00.0)$ \\
\hline \multicolumn{2}{|c|}{$51.8(-15.6)$} & $2,105.6($ & $2.2)$ & $194.5(-14.0)$ & $224.1(15.8)$ & \multicolumn{2}{|c|}{$323.3(-0.6)$} & $98.0(-00.0)$ \\
\hline \multicolumn{2}{|c|}{$51.8(-14.2)$} & $2,160.7($ & 4.9) & $188.2(-18.3)$ & $\begin{array}{c}\smile 72 \\
229.0(30.4)\end{array}$ & \multirow{2}{*}{\multicolumn{2}{|c|}{$317.9(-1.9)$}} & $98.0(-00.0)$ \\
\hline \multicolumn{2}{|c|}{$51.9(-12.2)$} & $2,242.9($ & $9.5)$ & 173. $4(-25.0)$ & $227.5(15.3)$ & & & $97.0(-00.0)$ \\
\hline \multicolumn{2}{|c|}{$52.0(-11.3)$} & $2,245.9($ & $3.7)$ & $195.0(-13.9)$ & & & & \\
\hline \multirow{2}{*}{\multicolumn{2}{|c|}{$\begin{array}{l}51.8(-7.5) \\
52.0\end{array}$}} & $2,174.3($ & ) & 177.5( & $233.6 C$ & & & \\
\hline & & $2,177.1$ & & 158.1 & & & & \\
\hline
\end{tabular}

のサウジ・アラビアの生産の動きが, 当面の原油過㮃 を回避して，OPEC の結束にひびの入るのを防ぐ政 策に踏みきったものかどらか。 OPEC の当面の課題 もまた，価格を上げたり，值下げしたりすることでは なくて，急激な生産削減を行なわずに，原油価格をど ら維持するかにあるわけである。最近の外電によれ ば，9月14日開かれるウィーン総会では，原油価格を 12月末まで凍結するために，生産政策が検討されるだ ろらと伝えている。

\section{3）将来の原油需給}

アラブ産油国の生産削減にもかかわらず，昨年の世 界原油生産量は，ペトロリウム・タイムズ誌によれ ば, 28 億 460 万 $\mathrm{t}$, 前年比 $7.8 \%$ の増加であった。そ して, 同誌は, OPEC 諸国の動向および OPEC 以 外の地域の生産動向をもあわせて, 将来の原油需給を 第 2 表のように予測している。

同誌は, 70年代の後半に重点をおいて, 1977/78 年 までの世界の需要は，消費国各国とも，石油価格の高 騰によって,これまでのような無制限な石油輸入の方 針を再検討せざるを得ないし，今後 4 年間の石油需要 は，別の要因でも抑制されることも考慮すべきである とし, しかも, 原油生産は, アラスカ, 北海, 新しい 沖合油田等がまだ寄与できないので, $1977 / 78$ 年の生
産水準は，おおむね 33 億 1,600 万 $\mathrm{t}$ ，最大に見込んで も 36 億 5,500 万 $\mathrm{t}$ 前後，したがって1973年以前のよう な無制限な石油需要は, 賄いきれず, 結局, 世界の石 油需要を年率 $5 \%$ 以下にスローダウンせざるを得ない であろうと結論している。

長期的な石油需給については, 本年 3 月末ブリュッ セルで開かれた三先進地域会議（日本経済研究センタ 一, 米ブルッキングス研究所, EC 大学研究所の共同 会議) のレポートが注目される。

石油価格が 2 倍（ $1 \mathrm{bbl} / 7$ \$ と仮定）になるとすれ ば, 1985年の世界の総エネルギー需要は, 石油危機以 前に想定した石油換算 1 日めたり 1 億 6,220 万 bbl が, 1 億 4,600 万 bbl と約 $10 \%$ 減，石油では, 当初の 8,400 万 $\mathrm{bbl} /$ 日 加約 $23 \%$ 減の 6,500 万 bbl/日 に減少する と予測する。この予測は, 主要消費国の石油輸入需要 が, 石油価格の高騰の結果, かなり大きく後退して, 国内のエネルキー生産が相当増えることを予想しての 計算で，国によって大きな差が出てこよう。わが国で は，エネルギー資源がそしいので，国産エネルギーの 増産の余地はまずないが，北海に油田をもつヨーロッ パ，また国内に，石油，天然ガス，石炭などの資源を 豊富にもつアメリカでは, 自給率向上の余地が大きい ので, 輸入需要をそれだけ減少可能であろう。 
これに対して, 石油の輸出力は, 国情によって事情 は異なるが，一ぱいに増産をつぶける国，資源保存の ため生産制限する国，長期的に収益堌大を最大にする ため, 生産制限で価格をつりあげようとする国, それ ぞれに分けられよう。将来の事情を考えての石油需給 バランスを試算すると第 3 表のように，1985年には輸 入量 3,500 万 bbl/ 日, 輸出可能量 5,500 万 $\mathrm{bbl} /$ 日, 差引 2,000 万 bbl/日 の供給余剩となって, 輸出可能 量は輸入必要量の約 $60 \%$ を上回る計算となって, 結果 は, 原油価格低下への大きな圧力となろらといらので ある。もちろん, このような計算には, 消費国, 生産 国の合理的な政策展開が前提とされているとはいえ, エネルギー問題は解決不可能ではないという結論は, 注目される。

また，アメリカ国務省石油顧問 W.レビー氏は，「自 由世界のエネルギー需要の増加率は, 1968 72 年の $5.6 \%$ に比し，1980年は $4.6 \%$ と見込まれており，こ の場合には, 石油消費は, 1968 72年の $7.5 \%$ の増加 率に対して，1980年まで $5 \%$ の増加になるはずであっ た。しかし, 石油価格の高騰のために, 消費の年増加 率は $2.7 \%$ でしか伸びられず，代替燃料が伸びること を前提として, エネルギ一供給は $3.3 \%$ 程度にとどま る事態も予想される」と論じている。

前記の三先進地域会議のレポートと同様に, レビー 氏も, 論拠に, 石油需要の価格弾力性をかなり高く評 価している点が指摘できる。一般に, 石油需要の価格 弾力性は, これまでどちらかと言えば小さいとされて きたのに対して, 石油危機以後の論者は, 逆に, その 高いことを論拠として, エネルギー需要の将来を予測 している。

\section{2. 原油価格の行方}

原油需給が，むしろ過鄱気味の傾向が強く，したが って, 減産の動きもめだってくるにつれて, 原油価格 の動きにも, 複雑微妙なむのがでてきつつある。 昨年12月23日の総会で, OPEC 各国は, 1974年 1 月 1.日からの原油公示価格を, 中東の標準原油 (marker crude) サウジ・アラビアのアラビアン・ライト（比 重 Api $34^{\circ}$ ) $1 \mathrm{bbl}$ あたり $\$ 11,651$ に決定した。それ 以来， 3 月， 6 月および 9 月の 3 回にわたって価格引 上げ（または改訂）の討議が，総会でなされてきた が，結果としては，1月決定の公示価格がそのまま今 日まで凍結されてきている。公示価格そのものは変っ ていないが，市場価格は，原油の供給事情や一部産油 国の事業参加事情もからんで，混乱気味である。その 市場価格が, ぞのような水準を示し, どのように変っ
て行くだろらかに，大きく関連している二つの大きな 動きがある。それには, 産油国の政府所有原油の入札 価格がどの水準にきまるか，そしてもら一つは，いわ ゆるバイバック価格（大手国際石油会社が，政府所有 原油を買戻すときの価格）が，どの水準で合意される かである。

本年 4 月頃から, 原油価格の実勢は, 部分的に低下 の兆しをみせてきたが，なかでも注目されたのは，こ れまで, OPEC 内で価格維持および值上げ政策を, 強硬に進めてきたりビアが，4月，5月契約価格を， $1 \sim 3$ 月の $1 \mathrm{bbl} 16$ \$水準から, 約 $20 \%$ 引下げ， 13 ドルを割る原油もでてきた。いわゆるバイ・バック価 格が，それまでの一応の基準とみなされてきた，公示 価格の $93 \%$ 以下に下げられることになってから，ナイ ジェリア原油も下がり傾向を示しはじめた。この動き は, やがて微妙に, 中東の原油市場にまで波及して行 った。

クエートは，4 月, 政府所有原油の本年下半期分 1 日あたり 125 万 bbl の入札を行なったが，応札者の才 ファーした価格が，政府の求めていた水準（公示価格 の93\%以上）に達しなかったという理由で拒否され， この入札は失敗に終った。石油会社の多くは, 公示価 格の $89 \%$ もしくは $10.25 \$ / \mathrm{bbl}$ の入札值を示したよう で, 各社とも，これまでの $93 \%$ 水準をかなり下回って いたといら。このクエートの入札は, 中東でこれまで 行なわれた最大のものだけに, 将来の原油価格に決定 的なインパクトを与えるものと，一般に見られてい た。とにかく,クエートは入札失敗の結果，大巾な減 産を断行すると同時に，政府所有原油を，事業参加の 相手石油会社の BP およびガルフ両社に，逆に公示 価格の $94.8 \%$ という高值をもってバイ・バックするこ とに合意し，軟化傾向の石油市場を驚愕させることに なった。

一方， イランの下半期分 $215,000 \mathrm{bbl} /$ 日 の入札も ごく少量の落札を除いて，大部分失敗に終っている。 エクワドルは最高 $40,000 \mathrm{bbl} /$ 日を 1 年分, チュニジ アは第 3.4 半期分 $30,000 \mathrm{bbl} /$ 日 を競売に付したが, 一様に買手がつかなかったということである。原油の 高值期待の入札は，ほとんどすべてが失敗であった。

アルジェリアは，イランとともに，これまで原油価 格引上げの急先鋒であったけれど，一般的な市場動向 に抵抗できず，ついに，第 3,4 半期分の販売価格を,

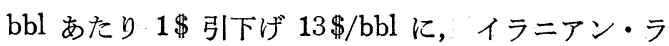
イト原油は公示価格の $86 \% に$ ，またナイジェリアのラ イト原油も $13 \$ / \mathrm{bbl}$ から $12.25 \$ / \mathrm{bbl}$ 一下落するな 


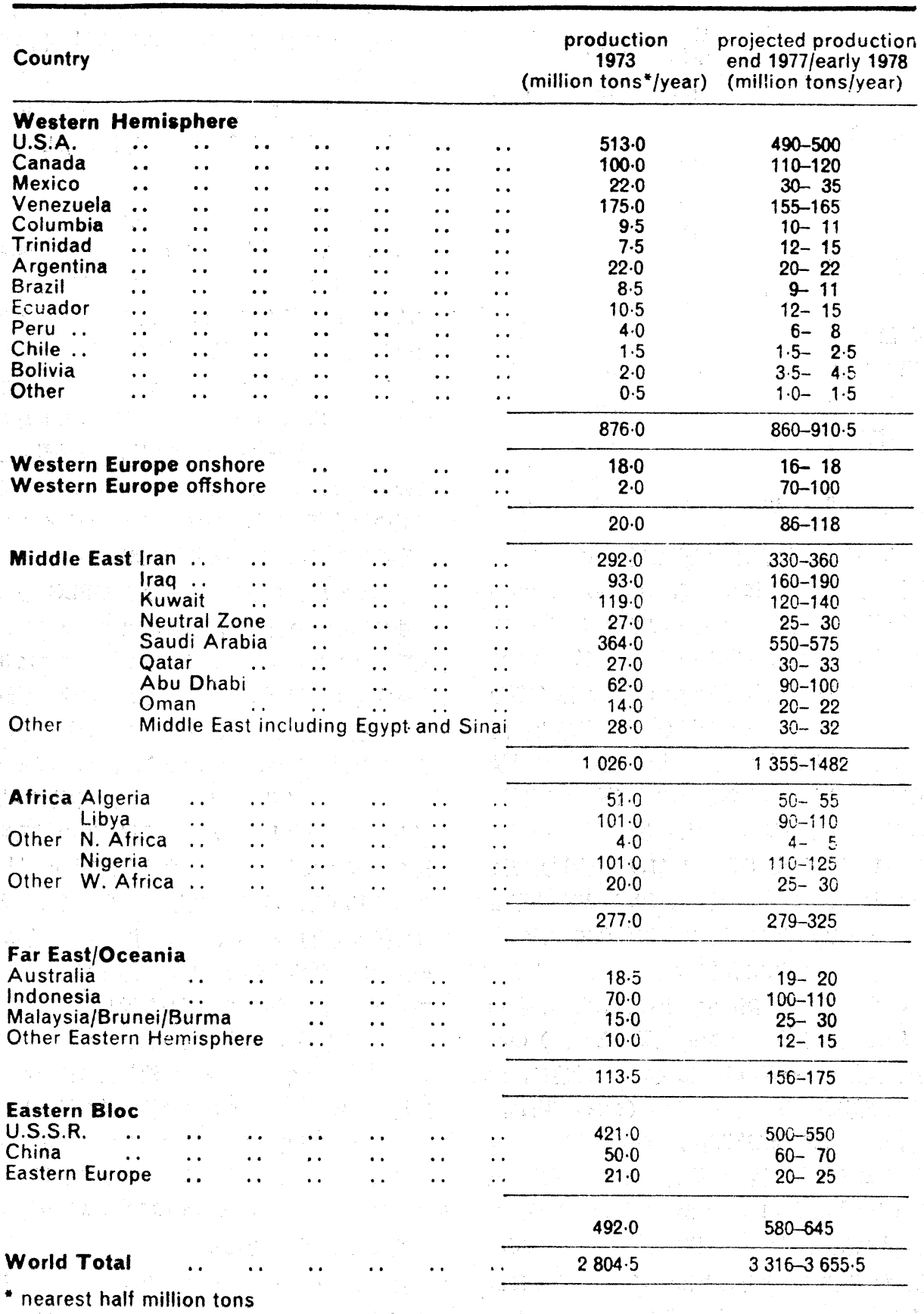

ど，各地にいくつかの值下げ例が続出して，中東，ア フリカ全体にわたって，原油スポット価格は，大きく 動摇しているよらである。

競売の失敗などから, スポット原油価格が, 軒並低
下の傾向を示しているなかで，価格動向に大きな影響 をもつ，も一つの要因であるバイ・バック価格につい て，注目すべき二つの対立する方向が出された。 本年になってからの新しい $60 \%$ の参加協定の改訂に 
表 3 石油輸入需要と輸出可能量のバランス試 算 (100万 bbl/日)

$\overbrace{1980}^{\begin{array}{l}\text { 1973. } \\ \text { 以前の予測 }\end{array}} \overbrace{1985}^{\text {改 }} \overbrace{1980}^{\text {訂 }}$

輸入 需 要

\begin{tabular}{|c|c|c|c|c|c|c|}
\hline$ア$ & リ & 力 & 10 & 13 & 2 & 3 \\
\hline$\exists$ & 一 ロッ & パ & 19 & 23 & 17 & 18 \\
\hline 日 & & 本 & 9 & 11 & 7 & 9 \\
\hline & 発途上 & 国 & 6 & 9 & 4 & 5 \\
\hline 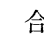 & 訣 & & 44 & 56 & 30 & 35 \\
\hline
\end{tabular}

輸出可能量

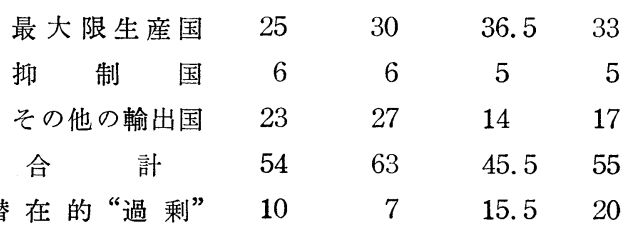

もとづいて，産油国政府と国際石油会社との間で合意 された最初の買戻し価格について，カタール石油の例 がある。1974年 4 月中旬, カタール政府とカタール石 油会社 (B.P., シェル, CFP の各 $23.75 \%$, エクソ ン, モービの各 $11.875 \%$, Pertex 5\%, 略称 QPC) およびシェル・カタール石油会社 (略称 SCQ) との両 社との間で合意された内容は, 各社合計で, 産油総量 のうち政府取得分 $60 \%$ のち最低 $60 \%$ （総量の $36 \%$ ） を，本年 $1 \sim 6$ 月平均価格，すなわち公示価格の $93 \%$ (QPC は $11,546 \$ / \mathrm{bbl}, \mathrm{SCQ}$ は $11.172 \$ / \mathrm{bbl}$ ) で買 戻すことを定めている。この例は，1972年12月湾岸諸 国が調印したリヤド協定の $25 \%$ 参加に代えて $60 \%$ 参加 を定めた，湾岸産油国での最初の例であった。ナイジ エリアは，4月 1 日付で実施すると発表した $55 \%$ 参加 （1973年 4 月以来 $35 \%$ 参加をシェル/BP と合意）のバ イ・バック価格を，つぎのように決めた。政府は，産 油量のうち 政府取得分の半分を各社 (シェル/B, P., モービル, ガルフ, Agip/Phillips, テキサス/Chevron, Safrap) が 13 \$/bbl で買戻す権利をあたえ（公示価 格 $14.691 \$ / \mathrm{bbl}$ の約 $81.6 \%$ ） かつ残量のうち半分を 13.25\$/bbl で買取る第一選択権を与えた。そして, 各社の買戻し価格は 3 カ月ごとに改訂されるらえに， 1975年 1 月 1 日からは，各社の販売できる量も減少 し, 政府取得分のうち各社が安い 価格で引取れる量 は，それまでの $27.5 \%$ から $13.75 \%$ に，選択引取量は それまでの $11.75 \%$ から $11 \%$ に制限され，さらに， 1976年 1月 1 日からは，引取原油（買戻し原油）も選 択原油も打切られ，各社は出資分の $45 \%$ のみとなると
いら内容であった。ナイジェリア政府は，5月に決定 したこのバイ・バック価格を， 7 月になって，市場の 軟化傾向を考慮して, 平均 $58.34 / \mathrm{bbl}$ 引下げ, $1 \mathrm{bbl}$ あたり 12.50 \$とした。この動きは, カタールのバ イ・バック価格にも反映して, 一部のメジャ一は, 公 示価格の $87 \% 10.80 \$ / \mathrm{bbl}$ ) を要求したとも報じられ ている。

以上にみられるように，政府のきめたバイ・バック 価格が，わずかの閒に，政府自から引下げねばならな かった例に対して，クエートは，逆に，公示価格の $94.85 \%(10.95 \$ / b b l)$ といら高值で, BP とガルフの 両社と合意して，供給過剩気味の世界市場を驚かせ た。公示価格の $94.85 \%$ というこの高値に合意した理 由として， B.P. もガルフも, 将来の入手をも考元, また他のメジャーズへの長期契約への影響をも考慮し てのものであったと伝えられているが，少なくとも， 最近の原油市場の動きのなかでは, むしろクエートの 合意は例外ではないかとの観測が多い。

本年 6 月 15 日のキトーにおける OPEC 総会では, 原油公示価格の引上げ, 引下げ論で, はげしい議論が 展開されたといらが, 結果としては, さらに 3 カ月, 9 月末まで現行の水準を据置くことに決定され，9月 に再び検討されることになったのは周知のとおりであ る。それにもかかわらず, 総会後, ベネズェラとイン ドネシアは， 7 月 1 日から, 前者は平均 $35 \% / \mathrm{bbl}$ を 引上げて, 平均 $1 \mathrm{bbl}$ あたり $\$ 14.43$ の新課税基準価 格を，そして後者は，原油 fob 価格を bbl \$11.70 から $\$ 12.60 ， 7.7 \%$ を引上げ，少なくとも本年 11 月 まで据置くと発表した。この両国は，ともに OPEC の決議には拘束されないといら態度を示しているもの ではあるが，これまでの例から推しても，このことに よって OPEC の価格政策を乱すようなことはまずな い。しかし, インドネシア原油価格の值上げで, 最も 影響をらけるのは，この国の約 $72 \%$ を輸入している日 本で，とくに原油生だきを拡大している電力業への傷 手は大きく，また原油価格とのスライド制をきめてい る, 将来のインドネシアの LNG 輸入コストにも大き く波及して行くことになろう。

最後に, バイバック価格の動きについて, 最も関心 の寄せられていたのは, サウジ・アラビアとアラムコ

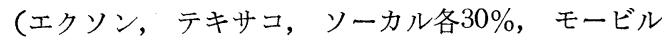
10\%出資）との参加交涉の成行きであった。両者は, 周知のよ5に，リヤド協定にもとづいて，1972年12月 $25 \%$ 参加協定に調印，本年 5 月に，暫定的に $60 \%$ 参加 に改訂，引きつづき本交渉を進めつつあるが，10月中 
には結論に達するのではないかという大方の見方でも ある。一方，原油競売についても，はやくから取沙汰 されてきたが，大方の予想を裏切って，無期延期にな った公算が大きい。この延期の理由について多くの憶 測があるが，一つには，アラムコの操業の $100 \%$ 所有 を実現して, 生産量の大部分をバイ・バックする交涉 を終えた後, 新しい市場価格を設定するためにもくろ んだものだといら見方が有力である。当初いわれてい た 150 万 bbl/日 の大量の原油が，政府の参加原油か らもたらされるのか, または原油の大部分が, 追加生 産によってもたらされるのかは, 湾岸産油国ばかりで なく， OPEC 全体の価格に非常に大きな影響をもた らすことになる。サウジ・アラビアの競争入札（セ リ) は, 中東原油の新しい標準価格 (marker price) を設定するものと考えられていた。サウジ・アラビア は，より低い原油価格を主張してきていたので，この 入札によって, あるいは湾岸のこれまでの標準価格で あった，公示価格の $93 \%$ を下回ることも起ったのであ ろら。入札延期の決定は, サウジ・アラビアが原油価 格引下げについて, 他の主要産油国（おそらくイラ ン）の支持をとりつけることができなかったことも大 きな理由ではないかといら観測もある。

原油価格の実勢は, かなり混乱している。軟化傾向 は依然として強い動きではあるが，それにもかかわら ず, アメリカでの多くのエネルギー専門家は「石油価 格值下がりの徵候は, 人を欺く不確かなもので, ほと んど期待できない」,「目下のところ大巾引下げのチャ ンスはない」,「大巾の価格低下など絶対にない」とい った意見で一致しているようである。そして，また， 石油価格の鍵を握っているのは, 主としてサウジ・ア ラビアであり, この国の入札や, 生産の大増加がな ければ, 世界石油価格に重大な引下げ圧力はあり得な いといら見方も一致しているようである。

\section{3. 国有化路線を進む産油国}

\section{1）参加比率の拡大}

穏健なアラビア湾岸産油国は, 他の急進的な産油国 とは別に, リヤド協定 (1972年12月調印)によって, 1982年までに段階的に，51\%まで，事業参加を進める ことであった。これらの諸国でも，昨年以来急激に， 参加比率を高めて, 国有化へ実現を進める動きがはげ しくなった。筆者は，「1974年は国有化の年である」 と独り考えているものであるが， OPEC 12力国の大 半が，すでに国有化を実現しており，残る諸国も，お そらく, 本年中には, その帰趨（すう）が決定するの ではないかと思われる。
1960年代前半において,つとにインドネシアは完全 国有化を断行し, 現在, 外国石油会社は, 国営石油会 社ペルタミナのもとに, 生産分与方式による請負契約 で操業している。70年 6 月アルジェリアの外国石油会 社の利権は, フランス系会社を除いて, 全面的に国有 化されて, 国営石油会社ソナトラックの所有となっ た。国有化の動きは, こらして, 急進派の産油国の間 に急激に展開して行った。イラクでは, イラク石油会 社 (B.P., ンェル, エクソン, モービル, CFP の出資) が長い間の紛紏の結果国営石油会社 INOC に国有化 され,リビァでは, BP の油田接収以来, 昨年 6 月に はバンカー・ハント会社 $(100 \%), 8$ 月にはオクシデ ンタル (51\%), およびオアシス・グループ (51\%), 9 月にはテキサコ・ソーカルなどの合弁会社アモシー

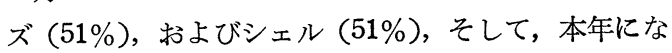
って，2 月にテキサコ・ソーカル・アルコの $100 \%$ 国 有化，3月には，シェル $100 \% ， 4$ 月にはモービル， エクソン $(51 \%)$ と，つぎつぎに，外国石油会社の国 有化を進めている。イランの国有化は, 古く50年代に 端を発しているが，新たに，1973年 6 月，コンソーシ ヤ厶 (B. P. 40\%，シェル 14\%，エクソン，モービ ル, テキサコ, ソーカル, ガルフ各7\%, CFP 6\%, 米独立系 $5 \%$ ）のもつ全資産を完全国有化し，将来 20 年間にわたって,メジャーズは生産原油の一定量の買 取権を与えられた。

本年になって, 湾岸産油国の参加問題が急速に展開 してきた。1月, クエート政府は, リヤド協定の内容 を不満として, 国会の批准が得られないままであった。 クエート石油会社との事業参加協定が，ようやく $60 \%$ 参加で合意がなり，5月に批准された。この事業参加 は，1979年までに，さらに検討されることになってい るので, 他の湾岸産油国 (とくにサウジ・アラビア) での動きによっては，100\% 国有化の時期は，それよ り以前になる公算も大きい。このクエートの決定の影 響は，4月のカタール政府のカタール石油拉よびシェ ル・カタール石油両社への $60 \%$ 参加決定に波及し, さ らには，5月のサウジ・アラビア政府とアラムコとの 60\%暫定協定の合意を促した。9 月になって, アブダ ビ政府は, アブダビ石油会社 (BP., シェル, CFP な

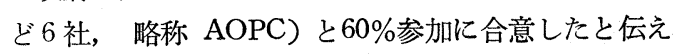
られ, さらに, アブダビ海洋開発会社 (BP., CFP., 海外石油開発など, 略称 ADMA) とも同様の参加交 涉を進める方針だという。これをもって, サウジ・ア ラビアをはじめ, 湾岸の主要産油国はすべて $60 \%$ 参加 を実現したことになるが, サウジ・アラビアとアラム 
コとの本格交渉は，実にこれからで，伝えられるよう な, 新しい内容をもつ $100 \%$ 参加方式が打出されるこ とにでもなれば，他の $60 \%$ 参加国も同様に，足並み を揃えて進むことになるであろら。一方, 西アフリカ のナイジェリアは, 本年 4 月, 大部分の石油会社（前 揭）に対し $55 \%$ の参加を実現し, 西半球のベネズェラ 政府も，1 年以内に，外国石油会社を全部国有化する ことを公表している。

2) 原油所有権の移転

OPEC 諸国の国有化は，あるいは70年代の後半を 待たずに，全面的に実現する可能性は，い上いよ大き くなったものと考えられるが, 参加比率の搪大, 国有
化への進展によって, 結果として発生する問題は, 生 産原油の所有権が大きく, 石油会社の手から産油国に 移って行くことである。100\% 国有化を待たずとも， すでに, 今日, 参加比率の急速な拡大で, 原油所有権 の移転は，はげしくなっている。第 4 表は, 1972年と 1973年の世界の所有者別原油生産量の推定であるが; いわゆるアメリカおよびイギリスの大手石油会社の所 有分はわずか 1 年の間に, 大巾な移動が生じてきたこ とが明らかである。したがって，本年中に展開された 参加比率の更新によって, その移動は, 地すべり的に 「その他」（産油国拉よびソ連）に大きく移って行くこ とであろう。

\section{表 4 世界の所有者別推定原油生産量}

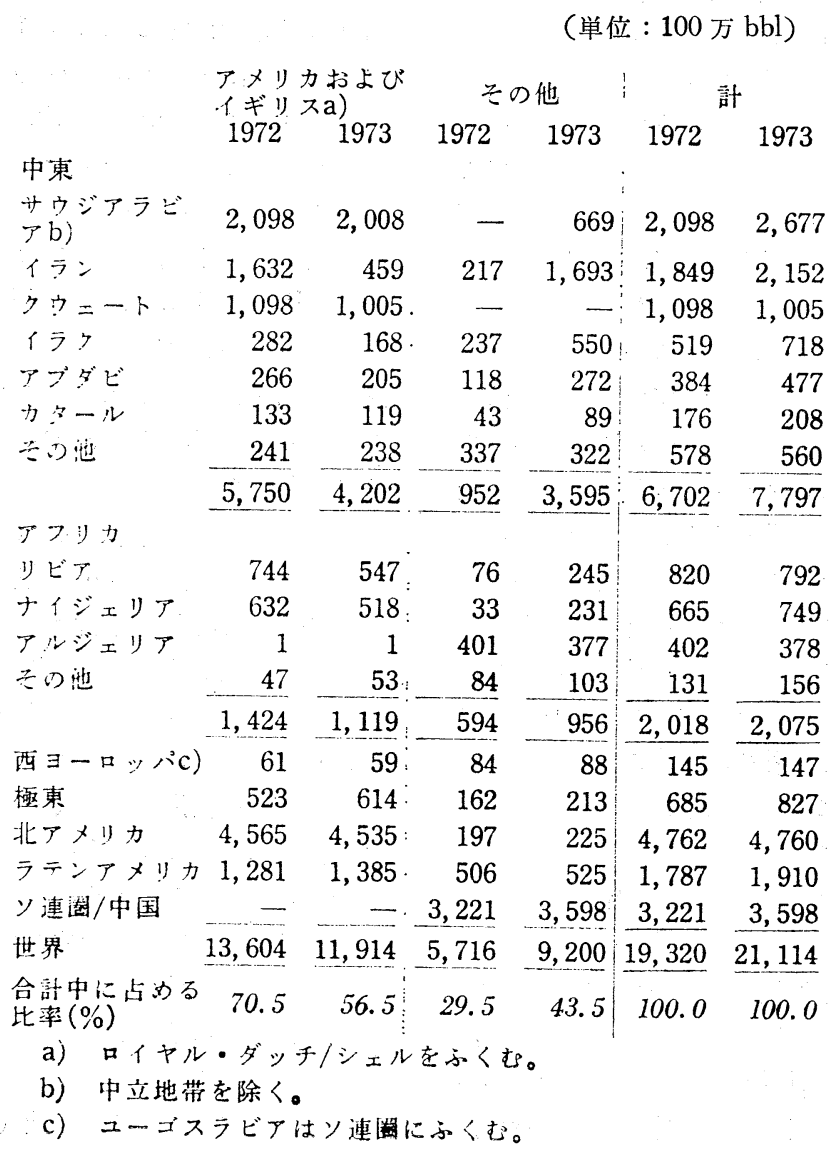

原油所有権の移転は,メジャーズの所有になる原油 量が，全般的に減少して行くことであるが，それは， メジャーそれぞれの原油自給率にも，大きく影響して くる。ここ数年間, 自由世界におけるメジャ一の原油 生産シェアは，おおむね $65 \%$ お $67 \%$ 占めてきたが，
本年の参加比率の拡大などによって，そのシェアは， おそらく60\%ぐらいまで縮減して行くであろう。した がって, 既存の原油供給ルートにも, 大きな影響が現 われてこよう。

国有化への進展によっては，これまでのすべての利 
権関係は消滅する。やがて利権料や所得税の計算基礎 としか存在意義のなかった公示価格制度の終えんを迎 えることにもなるであろら。そのとき，原油価格は， 何を基準として決められて行くであろらか。

\section{4. 消費国の自立化政策}

\section{1) $2 つ の$ 自立化計画}

石油危機以来, 主要消費国のエネルギー需要は, 一 般に沈滞している。それには，前記のように，世界的 な景気の停滞や, 石油価格の大巾な引上げが影響して いることは言らまでもない。そらしたなかで，消費国 はいま, 石油価格の高騰からばかりでなく, 将来のエ ネルギー供給の安定をはかるために, 不安定な海外供 給源への依存から，できるだけ国内資源への復帰をめ ざす政策を模索している。アメリカは「Project Independence-1980」を，そして EC は「New Energy Policy Strategy」の展開をはからうとしている。

昨年11月, 石油危機のさ中にあって, ニクソン大統 領は，「エネルギー自立計画-1980」を国民に呼びかけ た。それ以後, 政府部内で具体化への作業手順が進め
られているという。その内容は, いまの段階では,「大 統領マスタープラン」から推測する以外にない。

オイル・アンド・ガスジャーナル誌の伝える「大統 領マスタープラン」の概要は第 5 表のとおりで,その 要点は, 今後エネルギー需要を年率 $2 \%$ に抑え, 国内 資源の石炭, 天然ガス, 原子力を増産することによっ て，1980年には, 必要輸入量をゼ口，1985年には石油 換算 1 日あたり 310 万 bbl 相当の, 輸出余力を確保す るといらものである。このプランは, マンハッタン計 画やアポロ計画と並ぶ National plan であるといわれ ているが，文字ど㧍り大胆なものであろら。それだけ に, この計画の実現可能性については, 各方面からの 多くの疑問と批判が出されているが，いくつかの前提 条件が充たされる可能性が小さいということで, 1980 年までの実現はまず困難であろらと一般には, 判断さ れている。しかし，1980年よりずっと将来へ向けての 自立化への方向へ進んで行くであろう可能性は強いと 考えられる。

表 5 アメリカの大統領マスタープラン

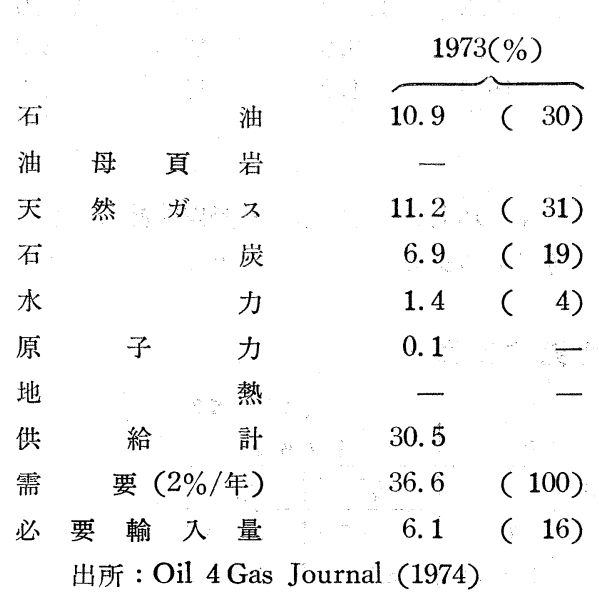

$\mathrm{EC}$ 諸国も，アラブ産油国への接近の姿勢を見せる 一方, アメリカの自立計画に対抗して強引な自立計画 を進めようとしている。

本年 3 月 21 日, $\mathrm{EC}$ 事務局は, レモネ副委員長の指 導のもとに, エネルギー新戦略の構図を委員会に提出 した。提案内容は, 供給の安定性に重点をおき1985 2000年までの長期の構想をたて, 需要は, 節減, 合理 化などにより，伸び率を $5 \%$ から 4\% に改訂し， 1973 ～85年の需要は $10 \%$ 削減されるだろらといらものであ
(単位, 石油換算 : 100 万 $\mathrm{B} / \mathrm{D}$ )

\begin{tabular}{|c|c|c|c|}
\hline \multicolumn{2}{|c|}{$1980(\%)$} & \multicolumn{2}{|c|}{$1985(\%)$} \\
\hline 14.0 & $(33)$ & 15.3 & ( 33$)$ \\
\hline 0.5 & ( 1 ) & 1.5 & ( 3$)$ \\
\hline 13.2 & $(21)$ & 15.0 & $(33)$ \\
\hline 11.0 & $(26)$ & 12.1 & $(26)$ \\
\hline 1.5 & $(4)$ & 1.6 & 4) \\
\hline 1.3 & $(3)$ & 2.6 & $(6)$ \\
\hline 0.6 & $(1)$ & 1.0 & $\left(\begin{array}{l}2 \\
(2)\end{array}\right.$ \\
\hline 42.1 & & 49.6 & ( 107$)$ \\
\hline 42.1 & $(100)$ & 46.5 & $(100)$ \\
\hline 0 & ( 0$)$ & $\triangle 3.1$ & $(\triangle 7)$ \\
\hline
\end{tabular}

る。シモネ案は, 石油危機以前の見とおしを大きく変 更しているが，その主なる点は，1985年時点での石油 依存度は，これまでの $61.4 \%$ であったのを，38.5\%に 落としたこと，天然ガス，原子力，石炭をそれぞれ $16.1 \% \sim 25.0 \%, 9.6 \% \sim 17.0 \%, \quad 10.5 \% \sim 17.5 \%$ へ 大きく引上げたことである。そして，1985年の輸入依 存率を $61.0 \%$ から $38.0 \%$ と大巾に削減をはかった点で ある。内訳については，つぎのように説明されてい る。まず, EC 域内の石炭生産は, 1973年の 1 億7, 900 
万 $\mathrm{t}$ を1985年に 1 億 8,000 万 $\mathrm{t}$ へ引きつぐ。すなわち, オランダ, ベルギー, 北フランスでの減産を, イギリ ス，西ドイッで埋めあわせる。域内石油生産は，1973 年 1,100 万 $\mathrm{t}$ から 1985 年 1 億 8,000 万 $\mathrm{t}$ 人大増産する。 地熱水力は， 1973 年の 2,700 万 $\mathrm{t}$ (石油換算) から, 1985 年 3,500 万 $\mathrm{t}$ ，原子力は 1973 年 1,400 万 $\mathrm{t}$ （石 油換算）から1985年 2 億 6,000 万 $\mathrm{t}$ （同）と想定して いる。

この計画も，アメリカの自立計画に似て，きわめて 大胆なもので，その実現については多くの困難が予想 されているが, 実は, その点からではなく, 本年 7 月
の EC 9 力国外相会議で，イギリスが，「提示された テキストはきわめて概括的な性格を有しており，ヨー ロッパのエネルギー政策確立によって提起されている 諸問題河等解決されない」という口実で, シモネ案 の承認を拒絶したことがあるが, 最近になって, 漸く 合意を得たようである。イギリスは，北海の石油開発 に大きな望みをたくしており，1980年時点では，自給 化が可能であるばかりか，あるいは石油輸出国にもな る可能性があるからだとの見方も伝えられているほど である。

表 6 EC 9 カ国のエネルギー消費みとおし

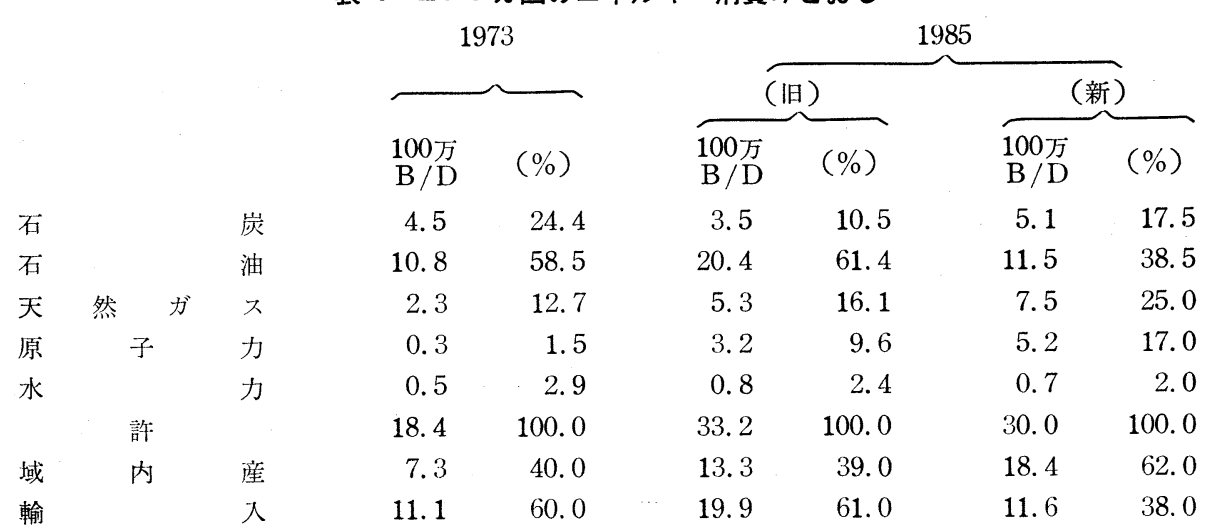

（ECエネルギー委員会 174.3）

2) 拡大寸る原子力計画

いまや，消費国各国での原子力発電への期待は大き
くふくれ上がっている。長期需給計画にもられている 原子力のシェアは，アメリカでも，ヨーロッパでも，

表 7 EC $の$ 原子力発電拡充計画

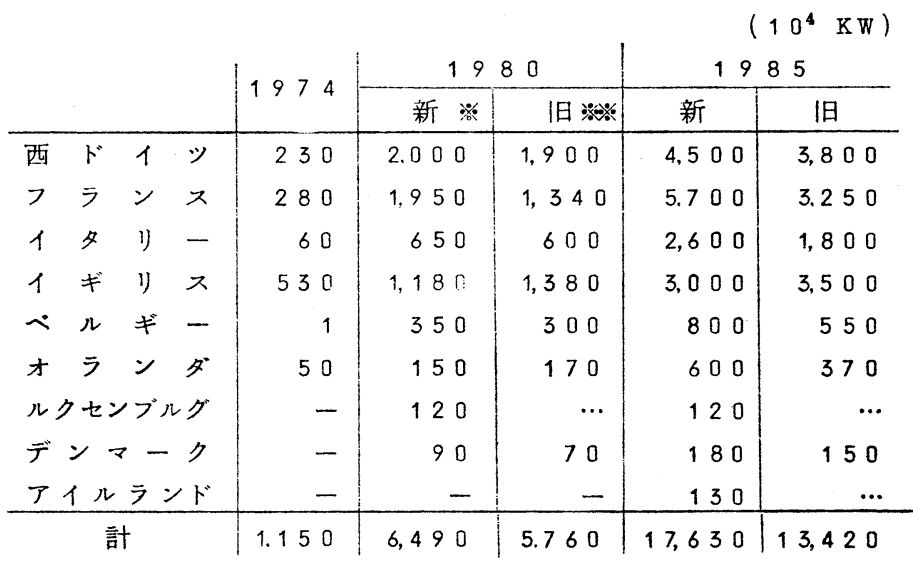

※ 新: 今回のヨーロッパ奖員会の推計

※旧：NEA、IAEAの1973年8月の推計 
(もちろん日本でも) 大きい。しかし，これまでの原 子力発電の進み方は, 予想を大きく裹切ってきた。ア メリカでは, 安全性について国民の関心が集中し, ま た技術面からの設備問題, 信頼性の問題, 労働生産性 の問題などで，建設が大幅におくれているという。し かし，1972年には 9 力所，1973年には15力所の新しい プラントが戦列に加わっており，本年中にはさらに17 力所が稼動に入るだろらとみられており, 今後 10 年間 には，100 カ所以上の建設が計画されている。1973年 末の原子力発電は, アメリカの電力のわずかに $5 \%$ に すぎないが, 現在建設中の発電力の約半分は, 原子力 発電であるという。1974年 1 月 1 日のアメリカの原子 力発電能力は, 54 台, 3,240 万 $\mathrm{kW}$ にのぼっている が，1985年末には，台数では 6 倍， 3 億 $\mathrm{kW}$ の能力 拡張が予想されている。

石油危機の事態に対応した EC 諸国の新しい原子力 発電計画が，このほど発表された。本年 1 月 1 日現在 共同体全体で 1,150 万 $\mathrm{kW}$ であるが，1980年には， 6,490 万 $\mathrm{kW}, 5.6$ 倍, 1985 年には 1 億 7,630 万 $\mathrm{kW}$, 15. 3倍が計画されている。なかでも, 西ドイッ, フラ ンスにおける大幅な計画桩大, イギリスの計画縮小が
注目される。

フランスは, 石油危機後, いちはやく新エネルギー 政策を作成し，果敢にこれを進めているが，エネルギ 一供給増加の主体に原子力を位置づけている。1974年 には 100 万 kW の原子力発電所を 6 基，1975年には 7 基着工する。稼動は1979年ないし1980年になる見込 みであるるが, 1980年までに合計40 50の原子力発電 所に着工することにより，1985年には，原子力発電に よる総出力は, 5,000 万 $\mathrm{kW}$ となり, 全電力の $7 \%$, 全エネルギーの $35 \%$ を占めることとなるという。

原子力発電への期待の大きい一例である。

最後に, 紙数の関係で, 触れることができなかった が，上記のような自立化計画は，当然に，長期的に実 現されなければならない性格のものであるだけに，そ れまでの期間のエネルギー需給バランスは，何はとも あれ，徹底したエネルギー・コンサベーション(節減) 以外にはないであろう。アメリカも， E C 各国も，こ の課題は, 当面の最大なものとして, その強力な推進 がはかられつつあることに，とくに注目すべきであ る。

\title{
Recent Energy Situations in Abroad
}

\author{
by Mutomi Sato
}

(The Institute of Energy Economics)

SYNOPSIS : - The supply and demand of crude oil has deen eased so much. They say, tanks of both consuming and producing countries are full of oil. Therefore, the producing countries in the Middle East Will try to maintain the present level of crude oil prices by reducing their production, While someone think of the price elasticity as such an important factor that the supply will overflow in near future.

The participation in the Gulf countries has made rapidly, the complete nationalization by the host countries will come in near time. This means that the disposal right of crude oil is to be transferred from majors to host countries. So the crude oil market in tne world will be changed so much.

Consuming countries, with taking into considerations after oil crisis, which include U.S.A., European countries and Japan, are [now introducing the new energy program like Project Independence of America. Above all, the construction of nuclear plants are most expected to expand. 